\title{
Perioperative Management of Acute Appendicitis in a Patient with Glutaric Aciduria Type 1
}

\author{
Michael S. Papageorgiou MD $\mathbf{P h D}^{1,2}$ \\ ${ }^{1}$ American Medical Center \\ ${ }^{2}$ Department of Surgery, Larnaca General Hospital
}

*Corresponding Author: Michael S. Papageorgiou, Poliniki 44, 2047, Nicosia, Cyprus. Email: mikpapageo@cytanet.com.cy

\begin{abstract}
Glutaric aciduria type 1 (GAl) is a very rare autosomal neurometabolic disorder caused by deficiency of mitochondrial glutaryl CoA-dehydrogenase. Patients develop neurological disabilities early in life, and need special medical and dietary treatment indefinitely. We report a case of a 16-year-old male patient with GA1, presenting with clinical signs of acute appendicitis who was subjected to surgery. The preoperative preparation, the intraoperative strategy and the postoperative management is described and discussed.
\end{abstract}

Keywords: Glutaric Aciduria type 1, Appendectomy

\section{INTRODUCTION}

Glutaric aciduria type 1 (GA1) is an uncommon metabolic disorder with autosomal recessive inheritance mode. The disease is caused by deficiency of mitochondrial glutaryl CoAdehydrogenase enzyme, which leads to the arrest of lysine, hydroxylysine and tryptophan metabolism ${ }^{[1]}$. This metabolism error causes excessive accumulation of organic acids such as glutaric acid, 3-hydroxyglutaric acid and glutaconic acid in the brain, thus resulting in neuronal damage. The global prevalence of the disease is 1:100000 newborns, although in certain countries the ratio alters dramatically (Sweden 1:30000, U.S.A. 1:50000), and also in certain ethnic groups (Amish societies 1:300). In Cyprus, the estimated prevalence is about 1:100000. Patients with GA1, if remain undiagnosed, present with dystonia, spasticity, rigidity, psychomotor delay and posture impairment. The disease can be diagnosed immediately after birth (countries such as Germany, Austria, Portugal, Spain, U.S.A. and others have routine newborn screening for GA) and with proper treatment, the patients have normal development. The treatment consists of carnitine supplements, low-protein diet and prevention of encephalopathic crises induced by stress conditions such as fever, infections, surgery etc ${ }^{[2]}$. In this case report we describe the preoperative preparation and the postoperative management of a 16-years old GA1 male patient with acute abdomen due to acute appendicitis from the surgeon's point of view.

\section{CASe Report}

A 16-year-old male Caucasian patient was referred to our Department of Surgery by a private hospital, with a possible diagnosis of acute appendicitis. He had a personal history of Glutaric aciduria type 1 (GA1), under treatment with L-carnitin $10 \mathrm{mg}$ once daily and specialized low-protein diet. His neurological status was quadriplegia and spasticity since infantry. The patient reported right lower abdominal pain for 24 hours, accompanied with an episode of vomiting. His parents reported a slight deterioration of the patient's neurologic status, with worsening of the spasticity. His vitals were stable (BP 106/60 $\mathrm{mmHg}$, pulse 90/min) and he had a temperature of $37,8^{\circ} \mathrm{C}$. Clinical examination revealed guarding of the right lower abdominal region with tenderness, while the McBurney and Blumberg signs were positive. Bowel movement was normal. Laboratory tests showed elevated WBC (13090/ $\mu \mathrm{l}$ with $88 \%$ neutrophils), while all the other results were in normal range. With the diagnosis of acute appendicitis, surgery was decided. We 
immediately contacted his pediatric geneticist and the Anesthesiologist Department, and we decided about the strategy needed, in order to prevent encephalopathic crisis and acute decompensation of GA1. We gave immediately $2 \mathrm{ml} / \mathrm{kg}$ of Glucose $10 \%$ solution $(120 \mathrm{ml})$, followed by $10 \mathrm{ml} / \mathrm{kg}$ of Normal Saline $0,9 \%$ $(600 \mathrm{ml})$ and we continued with Glucose $10 \%$ solution at a $300 \mathrm{ml} / \mathrm{h}$ rate, according to the British Inherited Metabolic Disease Group (BIMDG) recommendations. Intravenous antibiotic treatment was initiated (Cefuroxime $1 \mathrm{~g}$ three times a day and Metronidazole 500mg three times a day) and the patient was transferred to the operating theater. Anesthesia was performed with propofol and fentanyl. In surgery, gangrenous appendicitis with focal peritonitis was found and we performed typical appendectomy. After surgery, he continued antibiotic treatment, while he started the oral treatment with L-carnitine tabs 12 hours postoperatively. The fluid administration continued with a solution of Glucose $10 \% /$ Saline $0,45 \%$ with a rate of $200 \mathrm{ml} / \mathrm{h}$ for 12 hours, and afterwards, he started the low-protein diet. His postoperative course was uncomplicated and he was discharged on the $2^{\text {nd }}$ postoperative day with oral antibiotic treatment for another 3 days. The pathology report showed gangrenous appendix with multiple loci of necrosis. The patient in consecutive examinations in 3 days, one week and one month postoperatively, was found to have an unremarkable course, without any changes of his neurological status.

\section{DISCUSSION}

Glutaric Aciduria Type 1 (GA1) is a rare inherited autosomal recessive disorder caused by deficiency of glutaric CoA- dehydrogenase $(\mathrm{GCDH})$ [1,2]. In result of the GCDH malfunction, the metabolism of aminoacids such as lysine, hydroxylysine and tryptophan is stopped, leading to accumulation of organic acids, mainly glutaric acid, in the brain. This enzyme malfunction results in secondary carnitine deficiency as the concentration of organic acids is "neutralized" by carnitine.

The typical presentation of the disease is within the first year of life and patients with this condition are often born with macrocephaly and brain imaging reveals temporal atrophy with widening of Sylvian fissures. At an early point in life, patients develop a dystonic- dyskinetic syndrome, usually following an acute infection episode accompanied with fever and dehydration. At the moment of the episode and the following weeks, they present with hypotonia and choreoathetosis, which are later replaced by rigidity and dystonia. The final clinical presentation of GA1 is dystonia, spasticity, rigidity, which can lead to loss of communication, feeding and movement skills. Treatment includes a low-protein diet, adequate daily caloric intake and oral intake of carnitine supplements, which are all adjusted in cases of infection, dehydration or fever. In our case, the 16-years-old male patient presented with rigidity and dystonia, almost bed-bounded but with very good communication skills.

In recent years, neonatal screening for the disease, which is performed in many countries worldwide, has led to early diagnosis of the disease and subsequently early routine treatment commence. These measures have resulted in identification of patients as early as possible and elimination of most symptoms of encephalopathic crises, thus living close-tonormal or completely normal lives. Extreme awareness should always be present in the patient's family circle in cases of metabolical stress, such as fasting, infection, dehydration or fever. In these cases, an encephalopathic crisis is a real threat and emergency treatment is crucial, in order to avoid permanent deterioration of the neurological status. The basis of the emergency treatment is the high-energy intake, complete avoidance of protein intake, hydration and adequate carnitine intake. Of course, fundamental in this cases is the treatment of the underlying cause, which in our case was the acute appendicitis. Many reported cases in the literature point out that surgery, especially emergency surgery, is completely feasible in patients with GA1. Most of the articles are in the form of case reports, in patients presenting with intracranial hematomas, which is a frequent complication of the disease. ${ }^{[3-8]}$

In our case, as soon as the patient was referred to our Department, we immediately commenced the intravenous fluids administration regime, suggested by the British Inherited Metabolic Disease Group (BIMDG). It consists of i.v. administration of $2 \mathrm{ml} / \mathrm{kg}$ of Glucose $10 \%$ solution $(120 \mathrm{ml})$, followed by $10 \mathrm{ml} / \mathrm{kg}$ of 
Normal Saline 0,9\% (600 ml) and we continued with Glucose $10 \%$ solution at a $300 \mathrm{ml} / \mathrm{h}$ rate. Simultaneously, we started antibiotic treatment in order to reduce the septic complications and we informed the patient's pediatric geneticist and the Anesthesiologist Department. These two steps are essential in treating these patients, in terms of better and many times personalized treatment that they should receive. ${ }^{[9-13]}$

The postoperative course of these patients is almost as important as the pre- and intraoperative course. These patients should be closely monitored for postoperative complications such as hemorrhage or infections, which can again trigger a new crisis. At the same time, early oral intake should start, in order for the patient to gradually return to his/her previous metabolic state. We feel that in these patients after septic operations, antibiotic coverage should be rather extensive, so a complete regime of 5-days antibiotic coverage was administered, in order to avoid any septic complications. In addition to that, proper pain management should be applied, in order to manage surgical stress and pain, which can lead to a new crisis.

\section{CONClusion}

As a conclusion, GA1 is a very rare condition, which can complicate surgical diseases. The surgeon, who is at the time the treating doctor, should have a thorough understanding of the pathophysiology of the disease and the clinical manifestations. Furthermore, it is essential to have a continuous communication with the pediatric geneticist during the preoperative and the postoperative period, in order to recognize and treat complications as soon as possible. If all measures are applied, then the patients with Glutaric Aciduria type 1 can have an eventful surgery, with good outcome.

\section{REFERENCES}

[1] Lindner M, Kölker S, Schulze A, Christensen E, Greenberg CR, Hoffmann GF. Neonatal screening for glutaryl-CoA dehydrogenase deficiency. J Inherit Metab Dis. 2004;27(6):851-9. PMID: 15505392

[2] Kölker S, Garbade SF, Greenberg CR, Leonard JV, Saudubray JM, Ribes A, Kalkanoglu HS, Lund AM, Merinero B, Wajner M, Troncoso M, Williams M, Walter JH, Campistol J, MartíHerrero M, Caswill M, Burlina AB, Lagler F, Maier EM, Schwahn B, Tokatli A, Dursun A,
Coskun T, Chalmers RA, Koeller DM, Zschocke J, Christensen E, Burgard P, Hoffmann GF.Natural history, outcome, and treatment efficacy in children and adults with glutaryl-CoA dehydrogenase deficiency. Pediatr Res. 2006 Jun;59(6):840-7. PMID: 16641220

[3] Hernández- Palazón J, Sánchez-Ródenas L, Martínez-Lage JF, Collado IC. Anesthetic management in two siblings with glutaric aciduria type 1. Paediatr Anaesth. 2006 Feb;16(2):188-91.PMID: 16430418

[4] Zielonka M, Braun K, Bengel A, Seitz A, Kölker S, Boy N.Severe Acute Subdural Hemorrhage in a Patient With Glutaric Aciduria Type I After Minor Head Trauma: A Case Report. J Child Neurol. 2015 Jul;30(8):1065-9. PMID: 25038128

[5] Ituk US, Allen TK, Habib AS.The peripartum management of a patient with glutaric aciduria type 1. J Clin Anesth. 2013 Mar;25(2):141-5 PMID: 23352788

[6] Bishop FS, Liu JK, McCall TD, Brockmeyer DL. Glutaric aciduria type 1 presenting as bilateral subdural hematomas mimicking nonaccidental trauma. Case report and review of the literature.J Neurosurg. 2007 Mar;106(3 Suppl):222-6. PMID: 17465389

[7] Hartley LM, Khwaja OS, Verity CM.Glutaric aciduria type 1 and nonaccidental head injury. Pediatrics. 2001 Jan;107(1):174-5. PMID: 11134453

[8] Piatt JH Jr, Frim D. Glutaric aciduria type 1 and nonaccidental head injury. Pediatrics. 2002 Mar;109(3):554. PMID: 11875161

[9] Teng WN, Lin SM, Niu DM, Kuo YM, Chan $\mathrm{KH}$, Sung CS.Anesthetic management of comprehensive dental restoration in a child with glutaric aciduria type 1 using volatile sevoflurane. J Chin Med Assoc. 2014 Oct;77(10):548-51. PMID: 25107500

[10] Tsiotou AG, Malisiova A, Bouzelos N, Velegrakis D.The child with glutaric aciduria type I: anesthetic and perioperative management. J Anesth. 2011 Apr;25(2):301-4. PMID: 21221659

[11] Heringer J, Boy SP, Ensenauer R, Assmann B, Zschocke J, Harting I, Lücke T, Maier EM, Mühlhausen C, Haege G, Hoffmann GF, Burgard P, Kölker S.Use of guidelines improves the neurological outcome in glutaric aciduria type I. Ann Neurol. 2010 Nov;68(5):743-52.PMID: 21031586 
[12] Kölker S, Koeller DM, Okun JG, Hoffmann GF. Pathomechanisms of neurodegeneration in glutaryl-CoA dehydrogenase deficiency. Ann Neurol. 2004 Jan;55(1):7-12. PMID: 14705106
[13] Uezono S, Hotta Y, Takakuwa Y, Ozaki M. Acquired carnitine deficiency: a clinical model for propofol infusion syndrome? Anesthesiology. 2005 Oct; 103(4):909. PMID: 16192800

Citation: Michael S. Papageorgiou. Perioperative Management of Acute Appendicitis in a Patient with Glutaric Aciduria Type1. ARC Journal of Surgery.2017; 3(2):13-16. doi: dx.doi.org/10.20431/2455-572X. 0302004.

Copyright: (C) 2017 Authors. This is an open-access article distributed under the terms of the Creative Commons Attribution License, which permits unrestricted use, distribution, and reproduction in any medium, provided the original author and source are credited. 